\title{
Carbon Monoxide Measurement
}

National Cancer Institute

\section{Source}

National Cancer Institute. Carbon Monoxide Measurement. NCI Thesaurus. Code C139084.

The determination of the amount of carbon monoxide present in a sample. 